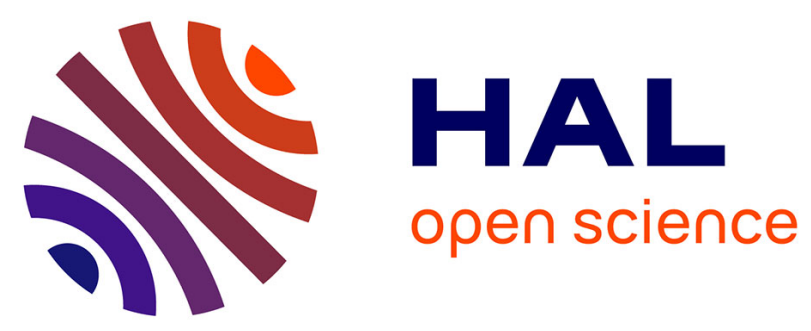

\title{
BOND ANGLE DETERMINATION BY ANGULAR EXAFS STUDY AND DEBYE-WALLER ANISOTROPY IN 2D GRAPHITE INTERCALATION COMPOUNDS
}

\author{
D. Bonnin, J. Bouat, P. Kaiser, Christian Frétigny, F. Béguin
}

\section{To cite this version:}

D. Bonnin, J. Bouat, P. Kaiser, Christian Frétigny, F. Béguin. BOND ANGLE DETERMINATION BY ANGULAR EXAFS STUDY AND DEBYE-WALLER ANISOTROPY IN 2D GRAPHITE INTERCALATION COMPOUNDS. Journal de Physique Colloques, 1986, 47 (C8), pp.C8-865-C8-868. 10.1051/jphyscol:19868167 . jpa-00226071

\section{HAL Id: jpa-00226071 https://hal.science/jpa-00226071}

Submitted on 1 Jan 1986

HAL is a multi-disciplinary open access archive for the deposit and dissemination of scientific research documents, whether they are published or not. The documents may come from teaching and research institutions in France or abroad, or from public or private research centers.
L'archive ouverte pluridisciplinaire $\mathbf{H A L}$, est destinée au dépôt et à la diffusion de documents scientifiques de niveau recherche, publiés ou non, émanant des établissements d'enseignement et de recherche français ou étrangers, des laboratoires publics ou privés. 
JOURNAL DE PHYSIQUE

Colloque $\mathrm{C} 8$, supplément au $\mathrm{n}^{\circ} 12$, Tome 47 , décembre 1986

BOND ANGLE DETERMINATION BY ANGULAR EXAFS STUDY AND DEBYE-WALLER ANISOTROPY IN 2D GRAPHITE INTERCALATION COMPOUNDS

\author{
D. BONNIN, J. BOUAT, P. KAISER, C. FRÉTIGNY and F. BÉGUIN* \\ Laboratoire de Physique Quantique, C.N.R.S. U.A. 421, \\ E.S.P.C.I., 10, rue Vauquelin, F-75231 Paris Cedex 05. France \\ ${ }^{*}$ C.R.S.O.C.I. - C.N.R.S. - I.P. 4221, 1, bis rue de la \\ Ferollerie, F-45045 orléans Cedex, France
}

Résumé: Les spectres d'un échantillon orienté de $\mathrm{RbC}_{8}$ ont été enregistrés pour des angles compris entre $0^{\circ}$ et $40^{\circ}$. Pour chaque pic de la transformée de Fourier, le rapport des amplitudes permet de calculer l'angle du vecteur $\mathbb{R}$ correspondant par rapport au plan. L'étude en fonction de la température entre $300 \mathrm{~K}$ et $35 \mathrm{~K}$ indique une anisotropie très importante du facteur de Debye-Waller, les amplitudes de vibration étant très importantes parallèlement au plan. Le second stade $\mathrm{RbC}_{24}$ montre un désordre statique très important par rapport au premier stade $R^{b} C_{8}$.

Abstract: Spectra of an oriented sample of $\mathrm{RbC}_{8}$ were recorded for a set of angles from $0^{\circ}$ up to $40^{\circ}$. For each peak in the Fourier transform, the amplitude ratio permits to calculate the angle of the corresponding $k$ vector with respect to the plane. The thermal study from $300 \mathrm{~K}$ down to $35 \mathrm{~K}$ shows a high anisotropy of the Debye-Waller factor, the amplitude of the vibration being larger in the plane. The second stage $\mathrm{RbC}_{24}$ shows a higher static disorder than the first stage $\mathrm{RbC}_{8}$.

Graphite belongs to the layered materials class, its intercalation gives several interesting properties for investigation of the $2 \mathrm{D}$ physics, previous works are referenced in [1]. The studied samples are intercalated with alkali metal, from Highly Oriented Pyro-Graphite. Experiments were performed at LURE-DCI on the two first stages (number of graphite layers between intercalant layers) : $\mathrm{RbC}_{8}$ and $\mathrm{RbC}_{24}$.

\title{
Bond angle determination
}

The absorption coefficient is treated as in the paper of Frétigny et al. [2] (this conference). The described method permits to obtain the $90^{\circ}$ spectrum from a set measurement angles from $0^{\circ}$ up to $40^{\circ}$. The shape near the $\mathrm{Rb} \mathrm{K}$-edge of $\mathrm{RbC}_{8} 1 \mathrm{~s}$ discussed in [2], the position of the threshold varies with the angle and the shift is 
about $5 \mathrm{eV}$ from the $0^{\circ}$ spectrum to the $90^{\circ}$ spectrum. Figure 1 corresponds to the EXAFS part, a very large increase can be observed in the amplitude of oscillations from $0^{\circ}$ to $90^{\circ}$.

The value of $\chi(k)$ varying with $\cos ^{2} \theta_{j}$, for one kind of neighbor, where $\theta_{j}$ is the angle between the polarization vector and the bond, it is necessary to calculate the mean value $\left\langle\cos ^{2} \theta_{j}\right\rangle$ because of the disorientation in the plane. The following formula is obtained: $\left\langle\cos ^{2} \theta_{j}\right\rangle=\cos ^{2} \alpha \sin ^{2} \theta+\left(\sin ^{2} \alpha \cos ^{2} \theta\right) / 2$ where $\alpha_{j}$ is the binding angle with respect to the c-axis and $\theta$ is the angle between the polarization vector and the ab plane.

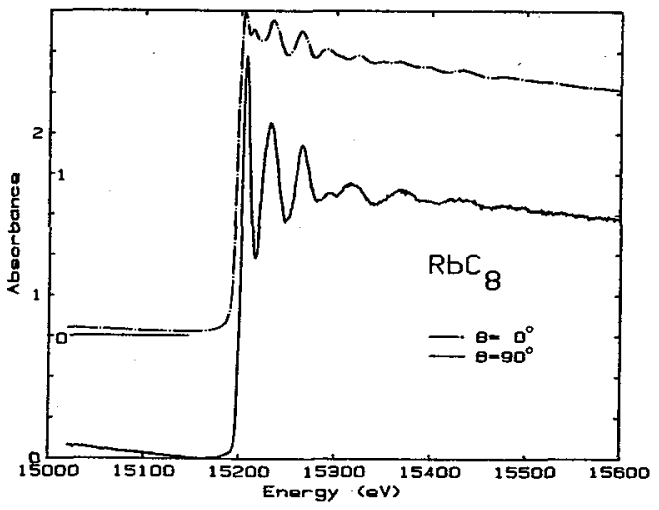

Fig. 1: EXAFS spectra of $\mathrm{RbC}_{8}$ for $\theta=0^{\circ}$ and $90^{\circ}$.

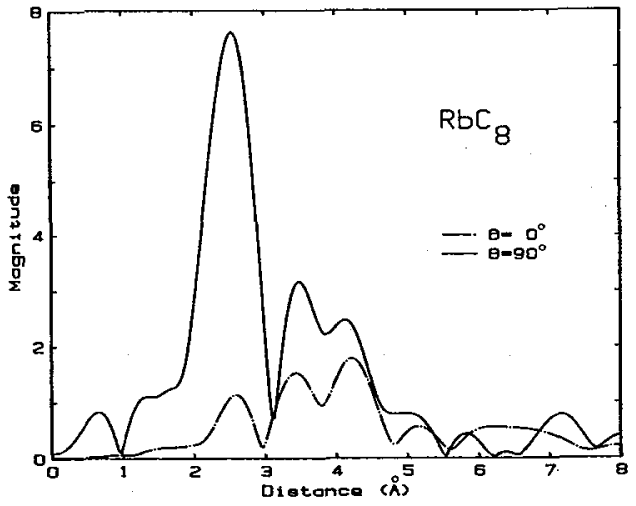

Fig.2: Fourier transform of spectra of Fig.1.

The radial distribution for the two perpendicular directions are shown figure 2. For each peak of the Fourier transform, the $0^{\circ}$ to $90^{\circ}$ amplitude ratio permits to calculate the angle of the corresponding $k$ vector with respect to c-axis, according to the formula:

$$
I_{0^{\circ}} / I_{90^{\circ}}=\left(\operatorname{tg}^{2} \alpha\right) / 2
$$

where I corresponds to the height of a peak of the Fourier transform. The obtained results agree well with the known structure of the first stage (figure 3 ). Moreover, that analysis does not need the knowledge of the type of neighbor. Comparison between

experimental and expected angles

\begin{tabular}{lccc}
\hline \multicolumn{2}{c}{$\begin{array}{c}\text { Distances } \\
\AA\end{array}$} & $\begin{array}{c}\text { Expected } \\
\text { angles }\end{array}$ & $\begin{array}{c}\text { Experimental } \\
\text { angles }\end{array}$ \\
\hline $\mathrm{Rb}-\mathrm{C} 1$ & 3.18 & $27^{\circ}$ & $31^{\circ}$ \\
$\mathrm{Rb}-\mathrm{C} 2$ & 4.02 & $45^{\circ}$ & $44^{\circ}$ \\
$\mathrm{Rb}-\mathrm{C} 3$ & 4.72 & $53^{\circ}$ & $50^{\circ}$ \\
$\mathrm{Rb}-\mathrm{Rb}$ & 4.92 & $90^{\circ}$ & $/$ \\
$\mathrm{Rb}-\mathrm{C} 4$ & 5.90 & $61^{\circ}$ & $/$ \\
\hline
\end{tabular}

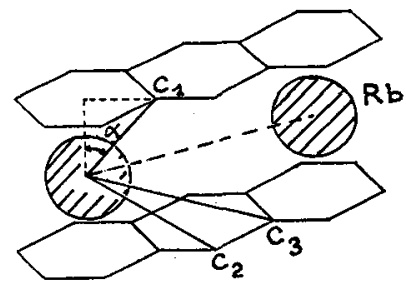

Fig.3: Local structure of $\mathrm{RbC}_{8}$ 
ARISOTROPY AND TEMPERATURE DEPENDENCE OF THE DEBYE-WALLER RACTOR

EXAFS spectra were recorded for a set of temperature $45 \mathrm{~K}, 70 \mathrm{~K}, 140 \mathrm{~K}$ and $300 \mathrm{~K}$. The experimental angle used is $30^{\circ}$ in order to have comparable intensities of the three first peaks of the Fourier transform of the low temperature spectrum. Figure 4 shows the temperature dependence of the Fourier transforms. higher is the order of the peak, higher the decrease of the amplitude. Taking into account the angles of the bonds, it appears clearly that the Debye-Waller factor is much more higher in the plane than perpendicularly. For each temperature and for each peak, we calculate the inverse Fourier tranform and obtain the quantities $x_{j}(T)$ relative to the peak $j$ at the temperature $T$. Then, the ratio $\chi_{j}(T) / \chi_{j}(45 \mathrm{~K})$ depends only on the Debye-Waller factor: $\log \left(x_{j}(T) / x_{j}(45)\right)=2 k^{2}\left(\sigma_{45}^{2}-\sigma_{T}^{2}\right)=2 k^{2} \Delta \sigma^{2}$

The variations of $\Delta \sigma^{2}$ are given on figure 5 , they permit the calculation of $\Delta \sigma_{1}^{2}$ and $\Delta \sigma_{\|}^{2}$. A very high anisotropy of vibrations is found due to the very large in plane value of $\Delta \sigma^{2}$. Because of the large Debye temperatures - $800 \mathrm{~K}$ out of plane and about $2000 \mathrm{~K}$ in plane - the carbon atoms belong to a very rigid network, their vibrations are neglected. So, there is no correlation effect in the $\sigma^{2}$ values, measured for the three first peaks, which correspond to the movents of $\mathrm{Rb}$ atoms. These results should be compared with dispersion phonon curves obtained by neutron spectroscopy.

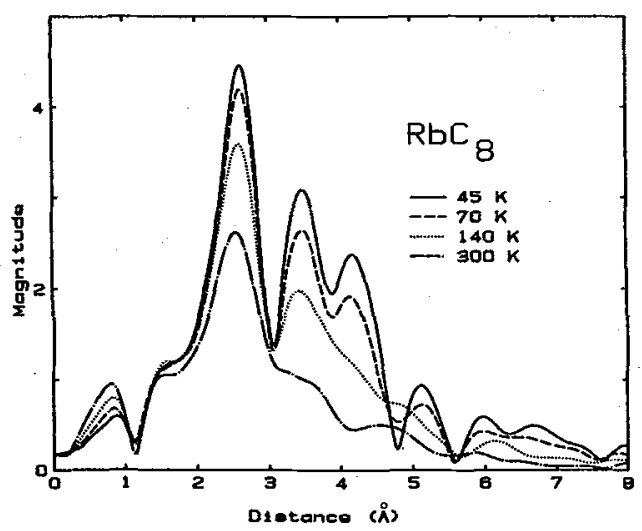

Fig. 4: Fourier transforms of spectra of $\mathrm{RbC}_{8}$ at various temperature and $\theta=30^{\circ}$.

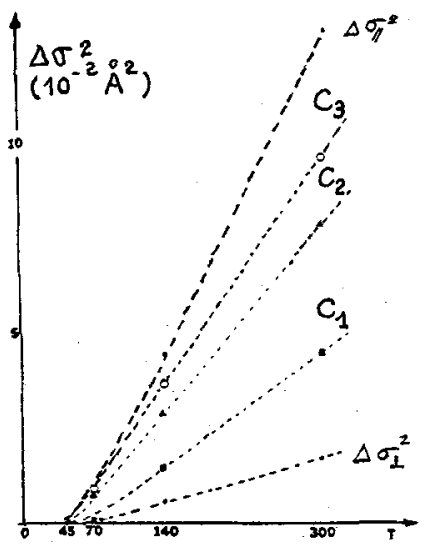

F1g.5: Temperature variations of the Debye-Waller factors in and out of plane.

Comparison between the stage $1-\mathrm{RbC}_{8}$ and stage $2-\mathrm{RbC}_{24}$

The magnitude of the FT of the low temperature spectrum $(40 \mathrm{k})$ at $\theta=0^{\circ}$ of $\mathrm{RbC}_{24}$ is about four time smaller for the two first peaks than those of RbC 8 (figure 6), moreover, the third peak dissapears in $\mathrm{RbC}_{24}$. The difference is attributed to a large static disorder in $\mathrm{RbC}_{24}$. Several simulations of powder spectra are 
tentatively made to describe the disorder. They are calculated taking into account the 88 first carbon neighbor atoms, the Debye-Waller factor and the mean free-path are considered to be isotropic. A good agreement is found for the two first peaks of $\mathrm{RbC}_{8}$, the third one is higher in the simulation than in experimental spectrum because of the simple model considered. The $\mathrm{Rb}$ atom is taken in front of the center of the carbon hexagon in the $\mathrm{RbC}_{8}$ simulation, three tests are made for $\mathrm{RbC}_{24}$;

a) Naylor [3] published a crystallographic structure, the check of which does not agree neither with the magnitude nor with the expected shape.

b) A model with only one kind of displaced Rb atoms is calculated, the shape of the FT depends dramatically on the position of the $R b$ atom. To obtain a spectrum which agree roughly with the measured one, the $R b$ atom must be about in front of a carbon atom. Nevertheless, the third peak does not disappear completely.

c) A model for which two kinds of atoms are consideredgives the best result. One kind corresponds to centered atoms, $11 \mathrm{ke}$ in $\mathrm{RbC}_{8}$, the other one corresponds to same amount of displaced atoms. By trial and error, a position is found to give a simulation which agree well with the experimental one (figure 7 ). The position of the displaced atom is given in the insert.

These models should be improved using a continuous distribution of sites.

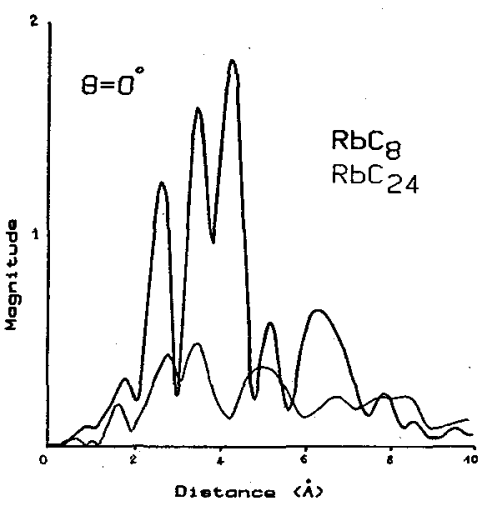

Fig. 6: Comparison of the spectra of $\mathrm{RbC}_{8}$ and $\mathrm{RbC}_{24}$ at $40 \mathrm{~K}$.

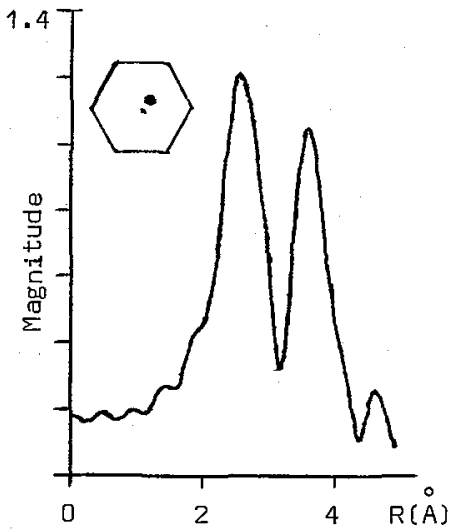

Fig. 7: Sinulation of $\mathrm{RbC}_{24}$ according to model c (see text).

\section{REPERENCES}

[1] Bonnin D. This conference and references therein

[2] Fretigny C., Bonnin D., Cortès $R$. This conference

[3] Naylor G.R.S. Appl. Surf. Science 22/23 (1985) 686 